\title{
Familielivets skyggesider: Religiøs genforhandling af transnationale steder og relationer
}

\author{
Af Mikkel Rytter
}

\begin{abstract}
This article discusses how and why some Pakistani migrants after forty years in Denmark experience various kinds of occult attacks, such as kala jaddu (sorcery), supposedly perpetrated by relatives in Pakistan who envy their success and prosperity. The emerging suspicions of occult intervention add transcendental qualities to the existing transnational social field stretched out between Pakistan and Denmark /Europe. The article suggests that the combination of distinct social mobility, on-going intergenerational negotiations of what it means to be and do family, along with the massive securitization of Muslim immigrants after 11 September 2001 have created a fertile ground for suspicions and conspiracies of occult attacks within and between migrant families. Finally, the article urges researchers of Islam to pay more attention to how religious technologies and imaginaries are used (and abused) to organise and reorganise family life and kinship networks.
\end{abstract}

I en artikel, der diskuterer forestillinger om himmel og jord blandt kristne konvertitter i Papua New Guinea ud fra et globaliseringsperspektiv, spørger antropolog Joel Robbins (2009) retorisk om trans- $\mathrm{i}$ transnationalitet er det samme som trans- $\mathrm{i}$ transcendens. Han svarer selv bekræftende og tilføjer, at det pågældende trans- har mange lighedstræk med det post- der optræder i vores konceptualisering af postmodernisme og postkolonialisme, idet der i alle tilfælde er tale om diskurser, som fordrer distance til eller afvisning af fortiden samt en positiv valorisering af fremtiden. Transnationalisme og transcendens adskiller sig imidlertid ved ikke blot at skabe distancere i tid, men også i rum, ved at skabe afstand til de lokaliteter, hvor folk tidligere har levet, det være sig et tidligere hjemland eller et jordisk liv, der ideelt set vil blive efterfulgt af et hinsides. Således bliver både transnationalitet og transcendens metonymer for strabadser der må overkommes og problemer man må lægge bag sig (Robbins 2009:69). Dette er godt set. Studier der kobler 'transnationalisme' og 'religion' er ofte to-dimensionelle i den forstand at de fx fokuserer på social organisering af kirker eller religiøse foreninger i forskellige lande, ser på dynamik i transnationale netværk samlet om en karismatisk leder, eller afdækker hvordan transnationale felter og religiøse forestillinger manifesteres og udbredes via cirkulation af ikoner, symboler, mennesker eller kapital. Der er imidlertid så vidt ikke mange studier, der inddrager transcendente dimensioner og kosmologier i analysen af, hvad det indebærer at leve transnationale liv (undtagelser er fx Csordas 2009; Rytter og Olwig 2011) ${ }^{1}$. 
Robbins' materiale beskæftiger sig med folk i Papua New Guinea, der føler sig mere eller mindre afkoblede fra globaliseringen og dens løfte om 'et bedre liv' (2009: 69). Anderledes forholder det sig med mange af de mandlige gæstearbejdere og familiesammenførte hustruer, der kom fra Pakistan i 1960erne og 1970erne og siden har boet og levet som immigrantfamilier i Danmark. Mange migranter har klaret sig godt fx som selvstændige erhvervsdrivende, mens deres børn, dansk-pakistanke unge, klarer sig så godt i det danske uddannelsessystem, at de til fulde matcher gennemsnittet af en dansk ungdomsårgang - og det uagtet at deres forældre ofte blot har en kort eller ingen uddannelse med sig fra Pakistan. Målt på denne succes er pakistanske familier langt fra marginale eller afkoblede fra globaliseringen, men tværtimod internationale migranter, der har evnet at indfri de løfter og forventninger om social, økonomisk og uddannelsesmæssig mobilitet, der er indlejret i de store fortællinger om migration og modernitet (Osella og Osella 2006). Trods deres succes er alt imidlertid ikke blot fryd og gammen; migranterne konfronteres i stigende grad med religiøse fænomener, som de ellers forbandt med familiens pakistanske fortid, landsbyliv og den 'mentalitet', som de mente at have lagt bag sig. Denne artikel diskuterer, hvordan enkeltpersoner og familier med muslimsk baggrund og rødder i Pakistan forholder sig til verserende mistanker om at de selv eller nogen i deres nærhed er offer for kala jaddu, dvs. intentionel ondsindet trolddom udført af en identificerbar anden - ofte et nært familiemedlem. Kala jaddu er imidlertid ikke blot et perifert indenfor islam², men i høj grad også et fænomen mange danskpakistanere forholder sig særdeles skeptisk til; des mere forvirrende bliver det, hvis forskellige konkrete hændelser i deres liv alle peger i retning af overnaturlig intervention.

Verserende mistanker om kala jaddu er en konsekvens af migranternes etablering i Danmark. Fra studiet af Pakistanske migranter i Manchester forklarer Pnina Webner: 'As migrants have travelled to the west so too have their afflictions and the harmful spirits associated with them. The global reach of Sufism is, it seems, also the global reach of jinns, jaddu and other malevolent influences' (Werbner 2003: 223). Mistanker om trolddom er yderligere blevet præsente og presserende i takt med at unge dansk-pakistanere, børn af de oprindelige gæstearbejdere, selv er blevet voksne og begyndt at stifte hjem og familie. Med denne transition fra 'barn' til 'voksen' er de begyndt at indtage nye positioner indenfor deres respektive familier - med tilhørende forventninger og forpligtelser overfor bl.a. ægtefæller, børn, forældre og svigerforældre. 
Jeg vil i denne artikel redegøre for fænomenet kala jaddu samt diskutere metodiske udfordringer ved at studere et sådant omstridt og tabuiseret emne. Dernæst præsenterer jeg en uddybende case om Shazia, en enlig mor i 30erne, med det formål dels at illustrere hvordan bekymringer og konflikter kan motivere mistanker om kala jaddu, dels hvilke modstrategier der kan iværksættes. Endeligt diskuterer jeg, hvordan det transnationale sociale felt som pakistanske migranter lever og agerer i har fået transcendente dimensioner og en udvidet kosmologi, hvilket resulterer i at personer og familier må forholde sig til at blive hjemsøgt af fænomener, de mente, hørte fortiden til.

\section{Forskning: fra forening til familie}

Der er ca. 25.000 mennesker bosiddende i Danmark med en pakistansk familie baggrund. Gruppen dækker overvejende danske, britiske og pakistanske statsborgere. Størstedelen af de familier, der kom til Danmark op gennem 1960erne og 1970erne, stammer fra mindre landsbyer i Gujrat og Jhelum distrikterne i Punjab. Resten kommer fra større byer som Rawalpindi, Lahore, Karachi eller Sialkot. Efter at have udført forfaldent arbejde på fabrikker og restaurationer begyndte mange i 1980erne som selvstændige, typisk som vognmænd eller indehavere af mindre butikker (Hjarnø 2000). Migrantarbejdernes børn, dvs. dansk-pakistanske unge, udmærker sig som nævnt ved et uddannelsesniveau, der matcher en bredere dansk ungdomsårgang og sammenholdt med forældregenerationens ofte korte uddannelse kan denne sociale mobilitet og opgør med 'den sociale arv' tolkes som en regulær succeshistorie.

De pakistanske migranter begyndte hurtigt efter ankomsten og bosættelsen i København at organisere sig omkring forskellige sociale, kulturelle og religiøse fællesskaber, man kendte 'hjemmefra'. Der blev blandt andet med tiden oprettet en række moskeer, så migranterne kunne få varetaget deres åndelige behov og senere bibringe deres børn et kendskab til koranens ord og islam generelt. Disse tidlige moskeer var imidlertid nationalt baserede og anvendte ofte forældrenes sprog og traditioner, hvilket betød at der fx opstod tyrkiske, pakistanske eller marokkanske moskeer (Simonsen 2001:171). Op gennem 1990erne begyndte unge med indvandrerbaggrund, herunder mange dansk-pakistanere, at oprette diverse ungdomsforeninger med varierende grader af religiøst indhold. Listen over ungdomsorganisationer og foreninger er lang og inkluderer blandt andet CEMYK (Council of European Youth Minority Commitees), OPSA (Organisationen af Pakistanske Studerende og Akademikere), MYL (Muslim Youth League), WYL (Women Youth League), FASM (Foreningen af Studerende Muslimer), MUNIDA (Muslimsk ungdom i Danmark), Kritiske 
Muslimer, Vision - den om lighed, MID (Muslimer-i-Dialog) og Dialog Forum (se fx Mørck 1998; Johansen 2002; Schmidt 2007; Rytter 2010a; Jacobsen 2011). Jørgen Bæk Simonsen skelner i denne forbindelse mellem migrantforældrenes 'defensive islam' og den nye 'offensive islam' (2001: 176). En tilsvarende revitalisering af religionen mellem to generationer af migranter er i international sammenhæng kaldt 'New islam' (Kibria 1998). De mange nye foreninger og organisationer var blandt andet kendetegnet ved deres samfundsengagement, der ofte udmøntede sig i forskellige forsøg på at skabe rum for og legitimitet omkring en 'dansk islam'. Via uddannelse og selvstudier af koranen, hadith, mm. forsøgte den yngre generation at distancere sig fra deres forældres mere nationale udlægninger af islam. Ideelt set var målet for mange af disse organisationer at rense religionen for diverse kulturelle traditioner og idiosynkrasier. Et væsentligt element i denne bevægelse var at distancere sig fra verserende spekulationer og fortællinger om nazar (onde øjne), jinns og jaddu, når ens forældre eller ældre i ens omgangskreds foreslog det som en gyldig forklaringsårsag til konkrete problemer eller konflikter.

I årenes løb har en del forskning således taget afsæt i mere eller mindre foreningsaktive immigranters udlægninger af islam og hvad det indebærer at leve som muslimsk minoritet $\mathrm{i}$ Danmark. Problemet er blot, at den megen forskning i særlige grupper, foreninger og politiske dagsordner har gjort os blinde for andre aspekter af islam - herunder hvordan islam formuleres og praktiseres i hverdagen indenfor familien og hjemmets fire vægge. Generelt er familien et domæne, der har fået forholdsvis lidt opmærksomhed i forskningslitteraturen, uagtet at det er væsentligt for børn og unges opvækst samt for overleveringen af religiøse forestillinger ${ }^{3}$. Den britiske antropolog Roger Ballard (2011) foreslår, at vi skelner mellem det han kalder padre og mādri muzhub ${ }^{4}$. Padre $m u z h u b$ dækker institutionaliserede former af ortodoksi og praksis, som de er formuleret af religiøse autoriteter og henvendt primært til mænd i moskeer eller andre offentlige rum. Omvendt sigter $m \bar{a} d r i$ muzhub mod mere uhøjtidelige overleveringer af religiøse ideer og praksisser i familien, herunder hvordan mødre, bedstemødre, søstre eller tanter kan anvende pragmatiske og beskyttende religiøse praksisser i deres børneopdragelse og organisering af hjemmet. Mādri muzhub og padre muzhub er således ikke kønsbaserede men kønnede domæner, indenfor hvilke religion antager forskellige former og funktioner (Ballard 2011: 33ff.). Mādri muzhub bliver vigtig i en migrationskontekst hvor familier aktivt må vedligeholde og genforhandle religiøse forestillinger og praksisser i nye omgivelser, der, efter terroranslaget den 11. september 2001, i stigende grad møder 
muslimske migranter med anfægtelse, regulering, mistro og overvågning (Ewing 2008; Bleich 2009; Pedersen og Rytter 2011).

Samlet vil en re-orientering af forskningsinteresser fra forening til familie samt fra de offentlige sfærer der udgør padre muzhub mod de private rum der udgør mädri muzhub åbne op for nye uudforskede aspekter af islam og muslimers hverdagsliv og religiøse praksisser.

\section{Studiet af kala jaddu og dens modtræk}

'Kala jaddu findes, det står i koranen!' Så bombastisk svarede Freha, en ung ugift dansk-pakistansk kvinde på mit spørgsmål om, hvorvidt man skal tage kala jaddu alvorligt. Med dette udsagn deler hun position med mange andre dansk-pakistanere, jeg har diskuteret spørgsmålet med. Gentagende gange er jeg blevet forklaret, hvordan magi blev bragt ind i verden af englene Harut og Marut for at teste mennesket. Og hvordan det senere, under Salaymans (Salomons) regeringstid, var ondsindede jinn, der lærte svage letpåvirkelige mennesker, hvordan de kunne udøve magi. Der henvises også til den hadith, der beretter om hvordan profeten Muhammad selv var ramt af sort magi ved en lejlighed. Det viste sig at være trolddom udført på ham ved hjælp af hår fra en kam, han havde brugt. I en drøm så han den brønd hvor det magiske objekt var placeret, så det dagen efter kunne blive fundet og destrueret - og trolddommen blive hævet (Ameen 2005: 182).

Indenfor antropologisk terminologi falder fænomenet kala jaddu ind under den bredere kategori af trolddom (sorcery), defineret som en ondsindet intentionel handling begået af en identificerbar anden. Ud fra denne definition bør kala jaddu ikke forveksles med nazar (onde øjne), der kategoriseres som hekseri (witchcraft), idet det udspringer af en persons bevidste eller ubevidste jalousi eller misundelse (jf. Sachs 1983; Svane 2011). Kala jaddu er en forhandlet og ofte omstridt social diagnose, der på en og samme tid forklarer konflikt eller ulykke og derved åbner op for konkrete handlerum og modstrategier. Det er en diagnose, der sættes under specifikke omstændigheder. Som det blev forklaret af forskellige informanter:

Kala jaddu er en måde, at få andres liv til at gå i stå fx ved at være skyld i deres skilsmisse, sygdom, at de ikke kan få børn eller ved, at der opstår ildebrand i deres hus. (Sofia, gift i 20’erne). 
Kala jaddu er når du er kørt fast; hvis fx du er en dygtig studerende, der klarer sig godt og så pludseligt dumper en eksamen og må gå hele semesteret om. I sådan et tilfælde vil folk begynde at mistænke, at noget må være galt [...] Du begynder at få mistanker om kala jaddu, hvis du lider ekstraordinært. Det er ikke ved en enkelt episode eller uheldig begivenhed, men når du kan se, at der er en systematik i de uheldige hændelser i dit liv, da er det, at man begynder at overveje om dette kan skyldes kala jaddu. (Irfan, ugift i 20'erne).

Efter en mistanke om trolddom har taget form, og den eventuelt er blevet bekræftet af signifikante andre, må man reflektere over sin livssituation for at identificere, hvem der kan (må) stå bag trolddommen, så man kan handle for at ændre på sine ulykkelige omstændigheder. Til dette formål anvendes en række forskellige religiøse teknologier, som fx det at bære en beskyttende tawiz. En tawiz gives af en pir (shaykh) og er en amulet, hvor udvalgte passager fra koranen er nedskrevet på papir og anbringes i et etui af læder eller metal, der så bæres om halsen eller armen. Det er koranens helende egenskaber samt evt. den pågældendes pirs barakat (velsignelse), der gør amuletten virkningsfuld. En anden, men lignende teknologi er dam, dvs. at få blæst på vand. Her vil en pir fremsige specifikke bønner eller passager fra koranen og puste på vand, som den person der ønsker beskyttelse efterfølgende kan drikke og således indoptage. Endelig kan en religiøs lærd eller imam give specifikke wazifa, hvilket kan være specifikke passager fra koranen eller forskrifter om, hvordan enkelte af skaberens 99 navne skal fremsiges et bestemt antal gange i forbindelse med de fem daglige bønner. Sådanne religiøse teknologier anvendes bredt i forbindelse med en person eller families stræben efter lykke, succes og velvære, men fungerer altså også som et konkret værn mod okkulte angreb.

Jeg har i løbet af mit feltarbejde i dansk-pakistanske familier forfulgt spørgsmålet om kala jaddu, hvilket ofte har ført til kortere eller længere pauser, hvor mine samtalepartnere har kigget vantro på mig og givet undret sig over, hvor jeg mon havde hørt om det. Nogle har kategorisk afvist, at det overhovedet skulle være et tema i Danmark, andre har modsat grebet mit spørgsmål og åbent fortalt om deres oplevelser og bekymringer. Langt de fleste har været forbeholdne i begyndelsen, men efter lidt tid talt sig ind på emnet. Nogle har berettet om egne erfaringer, oplevelser fra familiemedlemmer eller historier fra deres omgangskreds. En generel metodisk tilgang har således 
været at opsøge og forfølge historier og sladder om kala jaddu (jf. Marcus 1995). Flere forhold har imidlertid besværliggjort studiet af kala jaddu.

For det første taler man ikke åbent om sine mistanker, når det gælder kala jaddu. Ingen ønsker at blive til grin eller fremstå som overtroiske eller 'tilbagestående'. Mere fatalt er imidlertid, at man ikke kan stole på folk, da det altid er nogle i ens nærhed fx en bror, svigermor, nabo eller kollega, der, foranlediget af jalousi og misundelse, står bag de okkulte angreb. Derfor bliver konkrete mistanker kun diskuteret med de allernærmeste og mest betroede.

For det andet handler kala jaddu altid om konflikter indenfor husholdet eller familien. Den britiske antropolog Alison Shaw har givet en rammede opremsning af, hvor bredt den sociale diagnose kan anvendes indenfor pakistanske migrantfamilier i Oxford. Ifølge Shaw kan kala jaddu bl.a. anvendes til følgende:

[T]o harm an enemy or rival, such as a senior sister-in-law, to make someone agree with you, to make someone fall in love with you, to hide love affairs from parents, to control errant teenagers, to make a son accept a marriage he does not want, or to draw a husband's attentions, affections and duties towards yourself and your parents and away from your in-laws (Shaw 2000: 209).

Det kræver konduite, fortrolighed og diskretion at få folk til at berette om konkrete erfaringer og verserende mistanker, da kala jaddu ofte omhandler opskruede familiekonflikter, som de fleste ønsker at holde indenfor hjemmets fire vægge.

For det tredje står det klart, at alle der beskæftiger sig med kala jaddu bevæger sig væk fra islam; både hvis man selv udfører det, eller hvis man får andre til at udføre det, så gør man sig skyldig i shirk (blasfemi). Samlet er kala jaddu således et emne, ingen principielt bør vide noget om hvilket naturligvis besværliggør interviews (Rytter 2010b).

I næste afsnit præsenterer jeg en case om Shazia, der efter en skilsmisse havde konkrete mistanker om at være ramt af kala jaddu. 


\section{Shazia's familieproblemer}

Jeg besøgte Shazia i hendes lille lejlighed i København (tallene i teksten hen viser til tallene i figur 1). Hendes syv-årige søn var sendt i biografen med nogle venner. Efter sin skilsmisse havde hun boet næsten et år hos en veninde og hendes mand, indtil de bad hende om at flytte, derefter havde kommunen anvist hende en lejlighed.

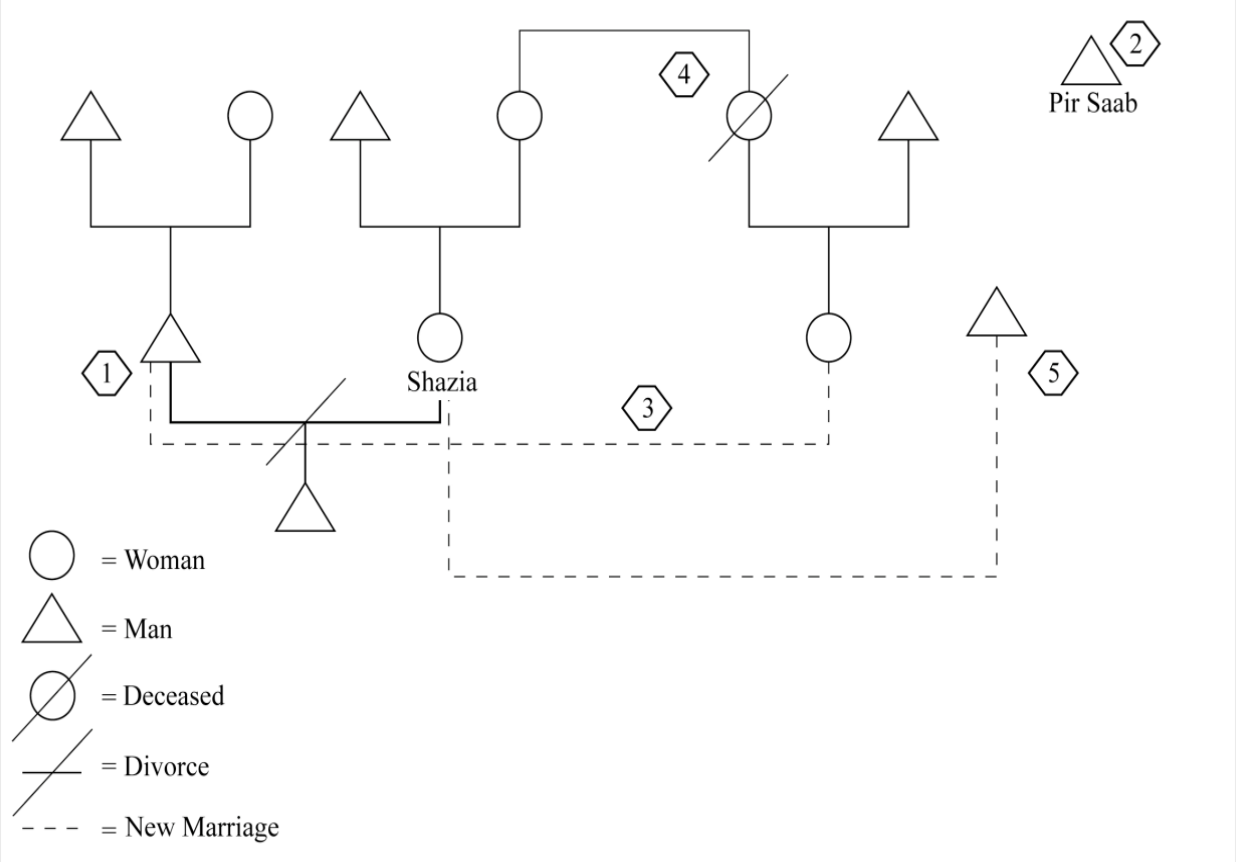

Figur 1 illustrer Shazia's historie.

År tilbage kom Shazia til Danmark. Hendes forældre havde modtaget rishta (ægteskabstilbud) fra en familie med oprindelse i deres landsby, men som nu boede i Danmark. Det var et godt parti. Derfor blev Shazia gift og kom til Danmark, hvor hun flyttede ind hos sin dansk-pakistanske mand og hans forældre i Frederiksværk (1). Det var ikke noget lykkeligt ægteskab blandt andet fordi de ikke fik nogle børn. Selvom Shazia efter seks års samliv faktisk fødte en søn, så blev de skilt umiddelbart derefter. Det forhold at Shazia have fået fuld forældremyndighed og anvist en bolig, kunne indikere, at der lå vold eller andre former for overgreb til grund for skilsmissen. Uanset hvad havde hendes mand i hvert fald aldrig haft et egentligt forhold til deres fælles barn. 
Shazia og hendes søn flyttede ind i et boligkompleks, hvor opgangene var aflåste og udstyret med dørtelefon. Derfor blev hun også overrasket, første gang hun fandt en pakke foran døren til sin lejlighed: 'det var en fin boks med mad og legetøj, én af den slags man får på McDonalds'. Shazia spurgte alle i sin opgang om det var dem, der havde stillet en boks for at glæde hendes søn, men det var tilsyneladende ikke tilfældet. Der dukkede imidlertid flere pakker op foran hendes hoveddør. Forvirret fortalte hun om episoderne til en 'auntie" ${ }^{5}$ det pakistanske miljø, der instruerede hende om aldrig at bringe pakkerne ind i lejligheden og afholde sig fra at spise deres indhold, da det kunne være en form for kala jaddu. Én gang havde Shazia’s søn fundet en af pakkerne. Han blev meget ked af det, da hans mor tog overraskelsen fra ham og smed den direkte i affaldsskakten. Shazia frygtede, at pakkerne var en form for kærlighedsmagi foranlediget af hendes tidligere mand og svigerfamilie, med det ene formål at få hendes søn til at holde op med at elske hende og i stedet alene elske sin far.

På det tidspunkt begyndte Shazia at lide under søvnbesvær og mareridt. Hun fortalte om sine genvordigheder til sin mor i Pakistan, der for at hjælpe kontaktede den lokale pir i landsbyen (2). Han bekræftede deres mistanke; Shazia's tilstand skyldtes kala jaddu iværksat af hendes tidligere svigerfamilie med det formål at skade og straffe Shazia for at have fået forældremyndigheden trods eks-mandens gentagende forsøg på at få denne tilbage via rettens vej ${ }^{6}$. Trods opfordringer afslog Pir Sahib at udpege direkte, hvem der stod bag ondskaben (fornuftigt i betragtning af at svigerfamilien også havde relationer til landsbyen). Som modtræk og for at få en frisk start besluttede Shazia at flytte væk fra Frederiksværk med sin søn. Hun fik anvist en beskyttet adresse af Københavns kommune, så hendes tidligere svigerfamilie ikke kunne antaste eller genere hende. Det var imidlertid blot et spørgsmål om tid, før hun igen skulle konfronteres med sin eks-mand, da han i mellemtiden havde giftet sig igen (3); denne gang med ingen ringere end Shazia's kusine (hendes mor’s søster's datter) og havde bosat sig syd for hovedstaden.

Shazia's mareridt fortsatte. Gentagende gange blev hun opsøgt i drømme af hendes nu afdøde moster (4), så igen kontaktede hendes mor i Pakistan den lokale pir, der denne gang anbefalede Shazia at konfrontere sin moster og lytte til, hvad hun havde at sige. Shazia fulgte hans råd. Mosteren kom for at bede om tilgivelse, fordi det rent faktisk var hende, der var skyld i Shazia's ulykkelige ægteskab og skilsmisse. Mosteren havde været misundelig på sin søster og sin nieces fordelagtige rishta i Danmark. Men hvis Shazia blev skilt fra sin mand, kunne hendes egen datter

(C) Forfatteren og Tidsskrift for Islamforskning, ISSN 1901-9580, publiceret 27-4-2012 
overtage hendes plads og den attraktive adgang til et bedre liv i vesten. Og det var netop sådan, det var gået. I døden angrede hun imidlertid de skader, hun og hendes kala jaddu havde forvoldt. Shazia tilgav hende. For at råde bod på sin udåd anbefalede mosteren en ung mand fra landsbyen som en passende partner for Shazia (5). Da jeg besøgte og interviewede Shazia, var hendes nye mand i Danmark for første gang på et turistvisum. Selv efter sin død havde Shazia’s moster stor indflydelse på hendes liv.

\section{Sociale diagnoser og skiftende fortolkningsrammer}

Shazia's fortælling er naturligvis personlig og unik, men rummer alligevel også en række af de strukturelle elementer, figurer og handlemønstre, som ofte optræder i fortællinger og mistanker om kala jaddu. For det første viser eksemplet med Shazia, hvordan uforklarlige hændelser og ulykkelige omstændigheder (som en skilsmisse eller gentagende mareridt) kan tolkes som udtryk for kala jaddu. Eksemplet viser endvidere, hvordan der reageres, når relativt fastlagte livsbaner brydes og nye retninger må udstikkes med det resultat, at forventede fremtidsscenarier og horisonter må tages op til genovervejelse. Her tilbyder kala jaddu som social diagnose dels svar på senmodernitetens kontingens og fundamentale usikkerheder (se fx Beck 1997), dels mulighed for at iværksætte modstrategier for at beskytte sig og få ens livsbane tilbage på en ønskværdig kurs.

For det andet illustrerer Shazias case, hvorfor kala jaddu (og trolddom generelt) er beskrevet i litteraturen som et 'weapon of the weak' (Scott 1985 i Ballard 2011: 44), dvs. en fortolkningsramme, der giver udsatte personer eller grupper et sprog til at tale om deres ulykke, samt rette en subtil - dog til tider direkte - kritik af de sociale magtstrukturer, hvori de er marginaliserede (se også Varley fortkommende). Shazia er en fraskilt mor, der ligger i en juridisk konflikt med sin eks-mand (og hans familie) om forældremyndigheden, og hun er ydermere en enlig migrantkvinde uden nogen familiemedlemmer i Danmark til at hjælpe og støtte sig. I sådanne tilfælde udgør forhandlede mistanker om kala jaddu en allegorisk arena, dvs. et legitimt sprog til at formulere en kritik af de magtstrukturer, hierarkier og skæbner, man er underlagt ${ }^{7}$.

Det er imidlertid langt fra alle, der er ligeså skråsikre som Shazia med hensyn til, hvorvidt deres sygdom, barnløshed, familiekonflikt eller økonomiske problemer reelt skyldes kala jaddu. Særligt blandt yngre mennesker med pakistansk baggrund opvokset i Danmark er der udbredt skepsis overfor fænomenets gyldighed, relevans og rækkevidde. Gentagende gange er jeg blevet forvirret 
over, hvordan informanter løbende syntes at skifte holdning til kala jaddu. Nogle gange kunne de fortælle lange udførlige beskrivelser af episoder, der underbyggede verserende mistanker, mens de andre gange slog det hen som 'forældrenes kulturelle mentalitet' eller 'overtro'. Denne omskiftelighed viste sig imidlertid at have sin egen logik. Jeg har i anden sammenhæng diskuteret, hvordan Tahir, en veluddannet dansk-pakistansk mand i midten af 30'erne, havnede i en konflikt med sin svoger - en konflikt, der hurtigt blev udlagt som motiveret af kala jaddu (se Rytter 2011). Tahir var imidlertid selv i tvivl om denne diagnose og bevægede sig mellem tre forskellige fortolkningsrammer. På den ene side holdt han fast i en sekulær logik hvor han, som en veluddannet moderne mand ansat i en international virksomhed, kategorisk afviste eksistensen af et traditionsbundet fænomen som kala jaddu. Andre gange præsenterede han sig selv som en rettroende muslim, der qua sin retskaffenhed var hævet over den slags folkereligiøse forestillinger og hvis kala jaddu endelig skulle findes, ville det ikke kunne ramme ham eller hans familie, fordi han efterlevede de rituelle forskrifter og religiøse forpligtelser indenfor islam. Endelig var han også draget mod at følge konspirationerne om kala jaddu, da dette vitterligt forklarede hvorfor han var havnet $\mathrm{i}$ en håbløs familiekonflikt og samtidigt åbnede op for nogle konkrete modtræk. Tahir havde det imidlertid meget ambivalent med denne tredje fortolkningsramme, da det samtidigt ville være en accept af det folkereligiøse univers og 'kulturelle mentalitet' han hele sin ungdom ${ }^{8}$ havde klandret sine forældre (og andre ældre i det pakistanske migrant miljø) for at tro og indgive sig på. For ham var kala jaddu, jinn, nazar osv. associeret med et liv i Pakistan, der burde være fundamentalt forskelligt og adskilt fra hans tilværelse i Danmark.

Umiddelbart peger eksemplet med Tahir i retning af et splittet subjekt eller personlighed. Det vil imidlertid være at overse en helt central pointe. De forskellige fortolkningsrammer, Tahir navigerer mellem, er del et personligt repertoire knyttet til hans identitet som dansk muslim med en pakistansk postkolonial historie og familiebaggrund. Dette er ikke en patologisk tilstand; der er derimod tale om 'shifting selves', der kan bevæge sig ind og ud af forskellige forståelses- og fortolkningsrammer og derfra tale om og tro på det ene i en sammenhæng for senere (nogle gange i næste sætning) at indtage det fundamentalt modsatte standpunkt med samme kraft, vitalitet og overbevisning (Ewing 1997) ${ }^{9}$. I sit studie blandt Pakistanske migranter i Manchester forklarer Pnina Werbner, at migranter kan (må) positionere sig forskelligt i sociale og politiske kontekster og navigere mellem et repertoire af identitetskonstruktioner som: 'british-pakistani-muslim-punjabiasian-black-mancunian-sunni-deobandi-jhemli-gujar' (2002: 64). Tilsvarende aktiveres forskellige

(C) Forfatteren og Tidsskrift for Islamforskning, ISSN 1901-9580, publiceret 27-4-2012 
fortolkningsrammer og identitetskonstruktioner, når dansk-pakistanere skal skabe mening ud af problemer og ulykke i deres liv - men hvis først kala jaddu er formuleret som en mulig social diagnose, kan denne mistanke være svær at ryste af sig.

\section{Okkulte angreb indenfor det transnationale felt}

Eksemplet med Shazia viser, hvordan trolddoms mistanker og deres forskellige modtræk fungerer i et transnationalt socialt felt (se Olwig 2003; Glick Schiller 2005). Pakistanske migranter i Danmark har altid været knyttet til de steder og mennesker, de forlod via forskellige transnationale praksisser; de første år ved brevskriverier, siden via billige telefonforbindelser, e-mails, Facebook, Skype, osv. Mange familier har cirkuleret videooptagelser af signifikante begivenheder her eller der, ligesom anseelige økonomiske investeringer er foretaget i prangende husbyggerier i landsbyen samt ved etableringen af lokale moskeer og infrastruktur. De fleste har foretaget kortere ferierejser eller haft længere ophold i Pakistan. Endelige er følelser og forbindelser til familienetværk blevet genbekræftet via transnationale arrangerede ægteskaber mellem dansk-pakistanske unge og ægtefæller fra Pakistan. Familier udstrakt mellem Danmark og Pakistan har således alle årene indgået $\mathrm{i}$ et transnationalt socialt felt karakteriseret ved simultanitet mellem forskellige lokaliteter, hvor hændelser det ene sted snart var kendt det andet (Levitt and Glick Schiller 2004). I dette perspektiv er verserende mistanker om trolddom, der ofte udspringer fra og modvirkes i Pakistan, blot endnu et aspekt af det transnationale sociale felt.

Der er flere eksempler i litteraturen på, hvordan verserende mistanker om okkulte angreb knytter an til transnationale sociale felter. I et studie af et omfattende familienetværk blandt pakistanske migranter viser Pnina Werbner, hvordan mistanker om kala jaddu kan være medvirkende til at intensivere familiekonflikter og afføde en kædereaktion af skilsmisser (1999). I et studie af tyrkiske migranter fra den Anatolske landsby Kulu bosat i en forstad til Stockholm gengiver Lisbeth Sachs (1983), hvordan en ung kvinde ikke kan (vil) forlige sig med det svenske sundhedssystem og lægers diagnose af hendes lille dreng. I stedet tager hun gentagende gange sønnen med tilbage til Tyrkiet for at få behandlet hans lidelse, der i følge moderen uvægerligt stammer fra nazar (onde øjne). Tilsvarende viser et studie af familier fra Bangladesh bosat i Storbritannien, hvordan forældrene til en dreng, der lider af Cockayne syndromet. vakler mellem forklaringsrammerne daktari (medicinsk) og upri (overnaturlig), og en deraf følgende behandling af enten en læge eller en religiøs healer afhænger af, hvilken diagnose der opstilles (Rozario 2009). Endelig viser Alyson

C Forfatteren og Tidsskrift for Islamforskning, ISSN 1901-9580, publiceret 27-4-2012 
Callan (2007), hvordan familiemedlemmer, der bliver ladt tilbage i Bangladesh, tolker og forstår deres egen afkobling fra migrationens og modernitetens forestillede lyksaligheder som resultat af overnaturlig intervention og ondsindet trolddom. Rækken af eksempler illustrerer, hvordan mistanker om okkulte angreb former livet i transnationale migrantfamilier - både for de, der rejste ud, og de, der blev tilbage.

I relation til danske forhold fortæller informanter ofte, at udøvere af kala jaddu findes i Pakistan: Man kan altid ringe eller få nogen dernede til at kontakte de personer, der er kendt og berygtet for mod penge at udføre kala jaddu. Det er da også typisk ens svigerfamilie, søskende, naboer eller forretningsforbindelser i Pakistan, man retter sin mistanke imod, hvis der er indikationer på kala jaddu i Danmark (Rytter 2010b). Modtræk i form af wazifa, dam eller tawiz erhverves ligeledes gerne hos en pir (shaykh) i Pakistan. Der syntes imidlertid også at være en gryende marked for Københavnsbaserede hjælpere. Som en af mine dansk-pakistanske venner udbrød i telefonen: 'Jeg ved ikke, hvad der sker, men pludselig er der 'hellige mænd' over det hele!' Dette var hans umiddelbare reaktion på, at ikke blot hans forældres tidligere nabo men også én af hans barndomsvenner begge var begyndt at modtage folk, give wazifa eller blæse på vand for dem.

Min vens udbrud indfanger imidlertid også noget af den skepsis, mange har overfor lokale hjælpere. Når det gælder modtræk mod okkult intervention vil mange have mere tiltro til en pir i Pakistan eller Storbritannien. Og hvis man ikke har mulighed for selv at konsultere en af disse, så er det meget belejligt, at København jævnligt besøges af piran $^{10}$ fra Storbritannien eller Pakistan, der rejser rundt i forskellige europæiske lande for at møde og hjælpe deres murideen $^{11}$ (følgere) og evt. udvide kredsen af folk, der følger dem (Nielsen et al 2003: 112-3). Der foregår således en omfattende cirkulation af personer og ydelser, hvilket er med til at opretholde og udbygge det transnationale sociale felt, der dækker forskellige destinationer i Europa (herunder Danmark) og Pakistan.

Det transnationale felt har i imidlertid - som anført i indledningen med henvisningen til Joel Robbins' arbejde - fået en transcendent dimension, der ophæver skel mellem tider og steder. Den transcendente dimension udgør et udvidet 'religio-scape' (Appadurai 1996), som dansk-pakistanere må forholde sig til og navigere i på den ene eller anden måde. Selvom de måske ofte har henvist fortællinger om jinn, nazar og kala jaddu til førstegenerationen, må også den yngre generation i dag

(C) Forfatteren og Tidsskrift for Islamforskning, ISSN 1901-9580, publiceret 27-4-2012 
forholde sig til, at livet i Danmark ikke er forskånet for den slags okkulte angreb. Som Rizwan, en ugift fyr midt i 30'erne meget præcist indfangede sin egen generations dilemma: 'Mange unge siger, at de ikke tror på kala jaddu, men det betyder jo ikke, at de ikke kan blive ramt af det’. Mistanker om kala jaddu er blevet et socialt faktum, som man må forholde sig til på den ene eller anden måde.

\section{Intimitetens forandring}

Det faktum, at også yngre dansk-pakistanere aktivt må forholde sig til okkulte religiøse fænomener, som de tidligere kunne afvise som overtro eller 'kulturel mentalitet', skyldes blandt andet ændringer af familieinstitutionen og en intimitet i forandring (Giddens 1992). For det første er der over de sidste årtier sket en markant demografisk forskydning indenfor gruppen af pakistanske migranter og deres efterkommere i Danmark. Den yngre generation er vokset op, har for manges vedkommende taget uddannelse og er begyndt selv at stifte familie og få børn. Denne transition fra 'barn' til 'voksen' betyder også, at man konfronteres med en række nye ansvar og forpligtelser overfor ægtefælle, børn, aldrende forældre og svigerforældre. Man vokser så at sige ind i et familieliv og en familiestruktur med etablerede moralske forestillinger om, hvordan relationer bør være og vedligeholdes. Hvis (når) sådanne forventninger skuffes, fører det til kritik og eventuelt konflikt og i værste fald brud.

Endvidere er selve migrantfamilien i forandring. Stadigt flere dansk-pakistanere gifter sig med ægtefæller fra Danmark. Disse ægteskaber er ofte, hvad der i emiske termer kaldes love marriages, dvs. de er blevet til på de unges eget initiativ og udgør således et brud med de mere traditionelle arrangerede ægteskaber, hvor det er forældres opgave og pligt at finde en passende ægtefælle til deres søn eller datter (se Rytter 2006). Når unge selv etablerer ægteskaber lokalt med eller mod familiernes vilje, vil det uvægerligt føre til ulmende konflikter. Her risikerer den danske del af familien at blive afskåret fra signifikante personer og steder i Pakistan (Rytter 2005). Med de mange love marriages er der endvidere sket en markant stigning i antallet af skilsmisser. Som Imran - der dengang endnu var ugift - med et glimt i øjet konkluderede: 'Måske er vi pakistanere faktisk ved at blive danskere!'.

Ofte vælger nygifte par at bo alene i stedet for at følge tradition med virilokale hushold, hvor i hvert fald én søn bliver boende hjemme hos sine forældre med sin hustru, efter at de er blevet gift. Det 
forhold, at unge vil have privatliv og frihed til at organisere deres hverdag og fremtid, som de selv finder bedst, er kim til mange kontroverser. Omvendt må mange af de, der rent faktisk vælger en ægtefælle fra Pakistan, flytte midlertidigt til Sverige eller et andet land indenfor den Europæiske Union for at omgås de stramme danske regler for ægtefællesammenføring indført i 2002. Dette har skabt den særlige 'Sverigesmodel', hvor ægtepar formelt er bosat i Sverige, men ofte reelt opholder sig en stor del af tiden i Danmark for at arbejde, studere, og besøge venner og familie (Rytter 2007, 2012). Familier bliver således splittet op som konsekvens af den aktuelle lovgivning.

De aktuelle stramme familiesammenføringsregler er imidlertid blot ét af mange tiltag, som den danske nationalstat har indført siden terrorangrebene den 11. september 2001 for at regulere og kontrollere de muslimske mindretal med henblik på at forhindre fremtidige terroranslag i Danmark. Hvor den første VK-regering fra 2001 havde et massivt fokus på at få indvandrere og flygtninge integreret på arbejdsmarkedet er der de senere år (særligt efter bomberne i London i juli 2005) primært fokuseret på 'integration' i relation til presserende spørgsmål om sikkerhed (Gad 2011). Denne udvikling har Erich Bleich kaldt nationalstatens 'security/integration-response' kendetegnet ved, at sikkerhedsdimensioner knyttes til den allerede eksisterende opmærksomhed på integration, og falder sammen med bekymringer om indvandring, kriminalitet og offentlighedens kobling mellem muslimer og vold (Bleich 2009: 355). Den omsiggribende sikkerhedsliggørelse af islam og danske muslimer er iværksat af handlekraftige politikere for at værne borgere, institutioner og velfærdsstat mod terroranslag. Uanset hvordan og hvorvidt disse forebyggende tiltag virker efter hensigten, så er sikkerhed for nogle (i dette tilfælde majoriteten) tilstræbt på bekostning af andre (i dette tilfælde minoriteten) (se Pedersen og Rytter 2011); en præmis, der skaber en grundlæggende usikkerhed blandt dansk-pakistanere og andre indvandrere med muslimsk baggrund om deres reelle muligheder for, at de og deres familie har en fremtid som ligeværdige borgere i det danske samfund, eller om de hellere skulle rejse til et andet land hvor de ikke diskvalificeres på grund af deres etniske baggrund og religiøse tilhørsforhold (Shakoor og Riis 2007; se også Bolognani 2007).

Sammenhængene mellem på den ene side en dansk-pakistansk migrantfamiliestruktur i turbulent forandring grundet social mobilitet og stramme familiesammenføringsregler, og på den anden side en generel samfundsudvikling i Danmark (og Europa og Nordamerika), hvor borgere med pakistansk og muslimsk familiebaggrund mødes med anfægtelse, kontrol og mistro, skaber det man, med en lille omskrivning af Anthony Giddens' (1991) begreb om 'ontologisk sikkerhed', kunne

(C) Forfatteren og Tidsskrift for Islamforskning, ISSN 1901-9580, publiceret 27-4-2012 
kalde ontologisk usikkerhed - hvilket igen danner en fertil grund for konspirationer og mistanker om okkulte angreb af forskellig slags.

\section{Familiens skyggesider og fremtidig forskning}

Jeg har i denne artikel slået et slag for, at vi i forskningsøjemed begynder at interessere os mere for den islam, der formuleres og praktiseres indenfor mādri muzhub, dvs. den private sfære, det hjemlige domæne og den lokale og transnationale familie generelt. Med afsæt i denne agenda har jeg diskuteret et ofte overset og / eller negligeret fænomen som trolddoms-mistanker indenfor migranthushold og familienetværker. I familielivets skyggesider foregår der løbende forhandlinger af, hvad der indebærer at være og gøre familie, samt i hvilket omfang et fænomen som kala jaddu skal placeres indenfor eller udenfor religionen islam. Artiklen viser imidlertid også, at der eksisterer en form for konsensus og veletablerede diagnoser til at bestemme, hvornår en hændelse kan (må) diagnosticeres som en okkult intervention, ligesom der findes en række forskellige religiøst baserede og sanktionerede modforanstaltninger. Med sit fokus på kala jaddu viser artiklen, hvordan det transnationale sociale felt strakt ud mellem Pakistan og Danmark har nogle karakteristiske transcendente dimensioner; dansk-pakistanske migranter risikerer ikke blot at blive ofre for intentionel kala jaddu, ramt af vilkårlig nazar eller hjemsøgt af drillesyge jinns, men kan samtidig også søge og finde modforanstaltninger ved at konsultere religiøse autoriteter og hjælpere i fx Pakistan, Storbritannien eller Danmark. Og selvom mange dansk-pakistanske familier måske nok mener, at de qua deres uddannelsesmæssige, økonomiske og sociale mobilitet i Danmark definitivt har distanceret sig fra deres fælles pakistanske landsby baggrund, bliver de stadigt fra tid til anden konfronteret med diverse uregerlige elementer fra deres fortid og tidligere hjemland.

Endelig har jeg i denne artikel foreslået forbindelser mellem en migrantfamilieinstitution i massiv forandring fx hvad angår ægteskabsmønstre, uddannelsesniveau, bosætningsforhold, tilhørsforhold, identiteter eller fremtidshorisonter generelt og så de omsiggribende tiltag den danske national stat siden terroranslagene i 2001 har iværksat for at monitorere og regere landet muslimske minoriteter. Hvordan interne familiedynamikker og eksterne indgreb i muslimske medborgeres liv og hverdag genererer usikkerhed på forskellige planer, fortjener imidlertid langt grundigere behandling, end det har været muligt at gennemføre i denne artikel. 


\section{Referencer}

Abu-Lughod, Lila, 1986: Veiled Sentiments. Honour and Poetry in a Bedouin Society, Berkeley and Los Angeles, University of California Press.

Ameen, Abu'l-Mundhir Khaleel ibn Ibrahim, 2005: The Jinn \& Human Sickness. Remedies in the light of the Quran and Sunnah, Riyadh, Darussalam.

Appadurai, Arjun, 1996: Modernity at Large. Cultural Dimnsions of Globalization, Minneapolis and London, University of Minnesota press.

Ballard, Roger, 2011: 'The Re-establishment of Meaning and Purpose: Mãdri and Padre Muzhub in the Punjabi Diaspora', i M. Rytter og K. F. Olwig (red): Mobile Bodies, Mobile Souls. Family, Religion and Migration in a Global World, Aarhus, Aarhus University Press, 27-52.

Beck, Ulrich, 1997: Risikosamfundet - på vej mod en ny modernitet, København, Hans Reitzels forlag.

Bleich, Erich, 2009: 'Muslims and the State in the Post-9/11 West: Introduction', The Journal of Ethnic and Migration Studies, 35(3): 353-360.

Bolognani, Marta, 2007: 'The Myth of Return: Dismissal, Survival or Revival? A Bradford Example of Transnationalism as a Political Instrument', Journal of Ethnic and Migration Studies 33(1): 59-76.

Callan, Alyson, 2007: “'What else do we Bengalis do?' Sorcery, overseas migration, and the new inequalities in Sylhet, Bangladesh', Journal of Royal Anthropological Institute vol. 13: 331-343.

Csordas, Thomas (red.), 2009: Transnational, Transcendence. Essays on Religion and Globalization, Berkeley og Los Angeles, University of California Press.

Ewing, Katharine Pratt, 2008: 'Introduction', in K. P. Ewing (red): Being and Belonging: Muslims in the US since 9/11, Russell Sage Foundation, 1-11.

(C) Forfatteren og Tidsskrift for Islamforskning, ISSN 1901-9580, publiceret 27-4-2012 
- 1997: Arguing Sainthood. Modernity, Psychoanalysis, and Islam, Durham and London, Duke University Press.

Gad, Ulrik Pram, 2011: 'Muslimer som trussel: identitet, sikkerhed og modforanstaltninger', i M. H. Pedersen og M. Rytter 2011 (red.). Islam og Muslimer i Danmark: Religion, identitet og sikkerhed efter 11. september 2001, København, Museum Tusculanum, 61-88.

Giddens, Anthony, 1992: The Transformation of Intimacy: Sexuality, Love and Eroticism in Modern Societies, Cambridge, Polity Press.

- 1991: Modernitet og Selvidentitet. Selvet og samfundet under sen-moderniteten, København, Hans Reitzels Forlag.

Glick Schiller, Nina, 2005: 'Transnational social fields and imperialism: Bringing a theory of power to transnational studies', Anthropological Theory 2005(5): 439-461.

Hjarnø, Jan, 2000: 'Indvandrere som selverhvervende - en sammenlignende analyse af udbredelsen af selverhverv hos danske pakistanere, tyrkere og eksjugoslavere', Dansk Sociologi 3/2000.

Jakobsen, Jens Stensgaard, 2011: 'Præmisser for dialog efter 11. september 2001.

Gülen-bevægelsen i danske offentlige sfærer', i M. H. Pedersen og M. Rytter (red.). Islam og Muslimer i Danmark: Religion, identitet og sikkerhed efter 11. september 2001, København, Museum Tusculanum, 245-268.

Johansen, Karen-Lise, 2002: Muslimske stemmer. Religiøs forandring blandt unge muslimer i Danmark, Viborg, Akademisk Forlag A/S.

Kibria, Nazia, 2008: 'The 'new Islam' and Bangladeshi youth in Britain and the US', Ethnic and Racial Studies, 31(2): 243-266.

Kublitz, Anja, 2011: 'The sound of silence: the reproduction and transformation of global conflicts within Palestinian families in Denmark', i M. Rytter og K. F. Olwig (red.): Mobile Bodies, Mobile

(C) Forfatteren og Tidsskrift for Islamforskning, ISSN 1901-9580, publiceret 27-4-2012 
Souls. Family, Religion and Migration in a Global World, Aarhus, Aarhus University Press, 161180.

Levitt, Peggy og Nina Glick Schiller, 2004: 'Conceptualizing simultaneity: A translocal social field perspective on society', International Migration Review, 38(145): 595-629.

Marcus, George, 1995: 'Ethnography in / of the World System: emergence of Multisited Ethnography', Annual Review of Anthropology 24: 95-117.

Mehdi, Rubya, 2008: 'Supernatural Means to Affect the Outcome of Family Disputes in Courts: The Case of Muslim Pakistanis in Denmark', i Mehdi, R., Petersen, H., Sand, E. R. og G. R. Woodman (red): Law and Religion in Multicultural Societies, København, DJØF forlagene, 197-216.

Nielsen, Jørgen, Mustafa Draper og Galina Yemelianova, 2006: 'Transnational Sufism: the Haqqaniyya', i J. Malik og J. Hinnells (red). Sufism in the West, London and New York, Routledge, 103-114.

Olwig, Karen Fog, 2003: 'Transnational socio-cultural systems and ethnographic research: Views from en extended field site', International Migration Review, 37(3): 692-716.

Osella, Caroline og Filippo Osella, 2006: 'Once upon a Time in the West? Stories of Migration and Modernity from Kerala, South India', The Journal of the Royal Anthropological Institute, vol.12(3): 569-588

Pedersen, Marianne Holm, 2011: "'You want your children to become like you". The transmission of religious practices among Iraqi families in Copenhagen', i M. Rytter og K. F. Olwig (red.): Mobile Bodies, Mobile Souls. Family, Religion and Migration in a Global World, Aarhus, Aarhus University Press, 117-138. 
- 2009: Practices of Belonging. Ritual Performances and the Making of Place and Relatedness among Iraqi Women in Copenhagen, Ph.D. series no. 52 Department of Anthropology, University of Copenhagen.

Pedersen, Marianne Holm og Mikkel Rytter (red.), 2011: Islam og Muslimer i Danmark: Religion, identitet og sikkerhed efter 11. september 2001, København, Museum Tusculanum.

Robbins, Joel, 2009: 'Is the Trans- in Transnational the Trans- in Transcendent? On Alterity and the Sacred in the Age of Globalization', i T. Csordas (red): Transnational, Transcendence. Essays on Religion and Globalization, Berkeley and Los Angeles, University of California Press, 55-72.

Rozario, Santi, 2009: 'Allah is the scientist of the scientists: Modern medicine and religious healing among British Bangladeshis', Culture and Religion, 10(2): 177-199.

Roy, Olivier, 2004: Globalized Islam. The search for a new ummah, New York, Colombia of University Press.

Rubow, Cecilie, 2000: Hverdagslivet teologi. Folkereligiøsitet i danske verdner, København, Forlaget Anis.

Rytter, Mikkel, 2012: 'The semi-legal family life: Pakistani couples in the borderlands between Denmark and Sweden'. Global Networks. A journal of international affairs, 12(1): 91-108.

- 2011: 'Demonic Migrations: Re-enchantment of Middle Class life among Danish-Pakistani Muslims', i M. Rytter og K. F. Olwig (red.): Mobile Bodies, Mobile Souls. Family, Religion and Migration in a Global World. Aarhus, Aarhus University Press, 53- 76.

- 2010a: "'A Sunbeam of Hope". Negotiations of identity and belonging among Pakistanis in Denmark' The Journal of Ethnic and Migration Studies, 36(4): 599-618.

- 2010b: 'In-laws and Outlaws: Black magic among Pakistani migrants in (C) Forfatteren og Tidsskrift for Islamforskning, ISSN 1901-9580, publiceret 27-4-2012 
Denmark', The Journal of Royal Anthropological Institute, 16(1): 46-63.

- 2007: 'Giftermål över Gränserne: Arrangerade Äktenskap bland Dansk-Pakistanier i Malmö', i M.

Eastmond og L. Åkesson (red.): Globala Familjer: Transnationel Migration og Släktskap,

Göteborg, Gidlunds, 175-204.

- 2006: 'Ægteskabelig integration. Pakistanske og danske arrangerede ægteskaber', i M. H.

Pedersen og M. Rytter (red.): Den stille integration. Nye fortcellinger om at høre til i Danmark, København, C.A. Reitzels Forlag, 18-43.

- 2005: ’ Ægteskab som bevægelse: Positioner og interesser i et arrangeret ægteskab’, i L. Gilliam, K. F. Olwig og K. Valentin (red.): Lokale hverdagsliv, fjerne forbindelser: Børn og unge $i$ migrationsprocesser, København, Hans Reitzels forlag, 265-283f

Rytter, Mikkel og Karen Fog Olwig (red.), 2011: Mobile Bodies, Mobile Souls. Family, Religion and Migration in a Global World, Aarhus, Aarhus University Press.

Sachs, Lisbeth, 1983: Evil Eye or Bacteria. Turkish Migrant Women and Swedish Health Care. Stockholm Studies in Social Anthropology no. 12. University of Stockholm.

Schmidt, Garbi, 2007: Muslim i Danmark - Muslim i Verden. En analyse af muslimske ungdomsforeninger og muslimsk identitet i årene op til Muhammad-krisen, Uppsala, Universitetstryckeriet.

Shakoor, Tallat og Rie Wellendorf Riis, 2007: Tryghed blandt unge nydanskere, Lyngby, Trygfonden.

Shaw, Alison, 2000: Kinship and Continuity: Pakistani Families in Britain, Amsterdam, Harwood Academic Publishers.

Simonsen, Jørgen Bæk, 2001: Det Retfcerdige Samfund. Om Islam, Muslimer og Etik, Viborg, Samleren.

(C) Forfatteren og Tidsskrift for Islamforskning, ISSN 1901-9580, publiceret 27-4-2012 
Svane, Lea, 2011: 'Field of tensions: Sufism, the republic and evil eyes in an Istanbul women's circle', i M. Rytter og K. F. Olwig (red.): Mobile Bodies, Mobile Souls. Family, Religion and Migration in a Global World, Aarhus, Aarhus University Press, 201-222.

Varley, Emma, Fortkommende: 'Black Magic, Divination and Remedial Reproductive Agency in Northern Pakistan', i B. Dupret, T. Pierret, P. Pinto og K. Spellman (eds.): Ethnographies of Islam, Edinburgh, The Aga Khan University Institute for the Study of Muslim Civilisations \& Edinburgh University Press.

Werbner, Pnina, 2003: Pilgrims of Love. The Anthropology of a Global Sufi Cult. London, Hurst and Company.

\section{- 2002: Imagined Diasporas among Manchester Muslims: The public performance}

of Pakistani transnational identity politics, Oxford, School of American Research Press.

- 1999: 'Global pathways. Working class cosmopolitans and the

creation of transnational ethnic worlds', Social Anthropology 7(1):17-35.

\section{Om forfatteren}

Mikkel Rytter har en ph.d.-grad i antropologi og er adjunkt ved Institut for Kultur og Samfund, Aarhus Universitet, hvor han indgår i det tværfaglige forskningsprojekt 'Sufism and Transnational Spirituality' (SATS) (se www.sufism.au.dk).

\footnotetext{
${ }^{1}$ Første udkast af denne artikel blev præsenteret på seminaret 'Muslimer i Transnationalitet' i januar 2011, arrangeret af Forum for islamforskning (FIFO) og forskningsprogrammet 'Sufism and Transnational Spirituality' ved Aarhus Universitet (se www.sufism.au.dk). Tak til alle deltagere samt til den anonyme reviewer for konstruktive kommentarer og forslag til hvordan argumentet $\mathrm{i}$ den endelige artikel kunne styrkes.

${ }^{2}$ Oplevelser af og modtræk mod fænomener som kala jaddu, nazar og jinn falder under den brede kategori som Olivier Roy kalder 'popular islam', defineret som: 'forms of worship that are not controlled by the ulama, but are not necessarily unorthodox. "Popular" does not refer to "lower" - class or rural populations; it concerns all social strata as well as urban dwellers' (Roy 204: 220).

${ }^{3}$ Signifikante undtagelser fra dansk sammenhæng er Pedersen 2009, 2011 og Kublitz 2011.

${ }^{4}$ Padre og mādri henviser til latinske betegnelser for kønnede fader- og moderlige sfærer, mes muzhub er af arabisk oprindelse og kan oversættes til sekt. Begrebsparret mādri and padre muzhub skal forståes som de to ender af et spektrum (Ballard 2011: 51).

${ }^{5}$ Betegnelsen 'auntie' (tante) er en gængs respektfuld og familiær tiltaleform for ældre kvinder i Pakistan og blandt dansk-pakistanere. I denne forbindelse indikerer betegnelsen også, at Shazia vægter og respekterer kvindens råd og vejledning. Hun hjalp i mange henseender Shazia og indtog således rollen som et egentligt familiemedlem.
} 


\footnotetext{
${ }^{6}$ Baseret på sine studier blandt Pakistanere i Danmark påpeger Rubya Mehdi (2008), at der ikke sjældent verserer rygter om anvendelsen af okkulte kræfter for at påvirke dommen i fordelagtig retning, når konflikter vedrørende arv, jordrettigheder eller forældremyndighed afgøres ved juridiske domstole.

${ }^{7}$ Lila Abu-Lughod's studie af Aw'Ali beduinerne i Egypten (Abu-Lughod 1986) fremhæves ofte som eksempel på, hvordan der på den ene side findes en manddomineret diskurs om blod og ære og på den anden side, hvordan beduin kvinder via sange og poesi kan fremsætte en kritik af deres position og skæbne. Jeg vil imidlertid foreslå, at en genlæsning af monografien også viser, hvordan der parallelt med æreskodekset og poesien er en sfære i hjemmene og familierne hvor mænd og kvinder mødes omkring fælles uro og bekymringer vedrørende jinn-besættelser, hekseri og trolddom. I Abu-Lughod's etnografi udgør diverse overnaturlige interventioner en allegorisk arena, et tredje sprog, hvorigennem sociale relationer og moralske ordner kan forhandles på tværs af kønnede domæner.

${ }^{8}$ Tahir har både før og under den tid, jeg har kendt ham, været særdeles aktiv i forskellige ungdomsforeninger og er således del af den ungdomsstrømning, Jørgen Bæk Simonsen kalder 'offensiv islam' (2001: 176) dækkende over unge med indvandrerbaggrund, der via politiske og religiøse aktiviteter kæmper for at skabe en legitim platform for sig selv som 'danske muslimer'.

${ }^{9}$ I sit studie af hverdagsreligiøsitet i Danmark foreslår antropolog Cecilie Rubow meget tilsvarende begrebet 'ontologiske cocktails' til at indfange det forhold, at vi alle bevæger os mellem forskellige, ofte uforenelige, fortolknings- og forståelsesrammer (2000: 244).

${ }^{10}$ Piran $=$ pir i plural.

${ }^{11}$ Murideen $=$ murid i plural.
} 